\title{
A kortárs magyar építészet és képzőművészet metszetei
}

\section{Sections of Hungarian contemporary architecture and fine arts}

\author{
A. HARANGI ${ }^{1}$, D. TÖRÖK ${ }^{2}$ \\ 1Debreceni Egyetem Műszaki Kar, hatt926@gmail.com \\ 2Debreceni Egyetem Műszaki Kar, david@dmbmuterem.hu
}

Absztrakt: TDK dolgozatomban a kortárs magyar építészet és képzőmüvészet metszeteit kutatattam. A történeti áttekintésben kristályosodott ki, hogy két fordulópont hatott napjaink művészetére - a gótikus és barokk összmúvészeti alkotások. Kortárs építészetünk és képzőmüvészetünk összemetsződéseit pedig három kategóriába soroltam: metamorfózis, kapcsolat és metszet. Az metszetekben valósul meg a legmagasabb szinten az összemetsződés. Ezt Megyik János képzômuúvész müvészetének elemzésével és a Debreceni Egyetem Élettudományi Épület és Könyvtár épületéhez készített Kapuzat szobrán keresztül fejtettem ki.

Abstract: In my study I have examined the sections of Hungarian contemporary architecture and fine arts. In the historical overview it has become clear that two turning points have influenced contemporary arts: the total art work (Gesamtkunstwerk) of the Ghotic and Baroque styles. I listed the sections in three categories: metamorphosis, relationship and section. The sections are the highest level of these categories. I explained my research in detail by analyzing these sections, at János Megyik's art and his Gate statue at Life Science building and library at the University of Debrecen.

\section{Bevezetés}

Építészmérnök hallgatóként sokat foglalkoztat az építészet és a képzőművészet kapcsolata. Számomra a kettő között sosem volt határ. Már több mint tíz éve tűzzománcozom. Körülbelül $15 \times 20$ centiméteres rézlemezekre festőzománc technikával készítek képeket grafikailag feldolgozva. Egy különleges megoldás által a képeim két rétegben léteznek, a felső rétegbe karcolt elemek által az alsó réteg felragyog. A két réteg közötti kapcsolat a kép lényege, tehát a vonal és teresedései a képeim legfontosabb alkotóeleme. Ez a megoldás egy absztrakt elvonatkoztatásra ösztönöz, úgy vélem ezen a gondolati síkon kereshetek kapcsolatot az építészettel.

Az építészet és a képzőművészet kapcsolata általános szinten egyértelmű, de mélyebben vizsgálva már nem magától értetődő. A kutatásom célja ezeknek a mélyebb rétegeknek a megértése, keretbe foglalása, és rávilágítani az építészet és a képzőművészet napjainkban észlelhető konkrét összemetsződéseire. 
A történeti áttekintés konklúziójában két pont van, ami meghatározó. Az első, hogy a középkori és különösen a gótikus építészetben valósul meg a legmagasabb szintű összművészeti alkotás. Az építészet, szobrászat és festészet teljes szintézisben születtek egy közös célért. A második, hogy a gótika után elkezdenek önállósulni a művészetek, az építészet elveszíti egyeduralkodó, koordináló szerepét. A barokk építészetben valósul meg az utolsó Gesamtkunstwerk, az építészet többé már nem fogja össze a művészeteket. Ettől a ponttól kezdődik az a folyamat ami napjainkban is tart.

A történeti fordulópontok és az ipari forradalom óta tartó embert meghaladó technikai fejlődés hatásainak vizsgálata a kortárs építészetünkre és művészetünkre a kutatásom vezérfonala. Úgy gondolom, hogy ennek a két folyamatnak a megértése választ adhat a jelenkori művészetünkre és a keresett metszetek újraértelmezésében is segítséget nyújt. A kortárs kapcsolatokat, mint alternatívákat kezelem, és az összemetsződéseket három kategóriába sorolom: metamorfózis, illeszkedés és metszet. Célom, hogy minél több oldalról feltárjam a kortárs építészet és képzőművészet kapcsolatát, amelyet Megyik János képzőművész életművének és művészetének elemzése alapján fejtek ki, kiemelt hangsúlyt helyezve a Debreceni Egyetem Élettudományi Épület és Könyvtárépületéhez készített Kapuzat szobrára

\section{1. Építészet - szobrászat - festészet}

Az építészet és képzőművészet metszeteinek meghatározásánál az építészet, mint térbeli művészet az elsődleges a tanulmányomban.

Elképzelhető, hogy az építészeti mű végső élményének kibontakozása folyamán a társművészeti alkotás minden bemutatott szerepkört betölt. Tartalmi jellegben a legmagasabb rangra is emelkedhet, közvetlen építészeti alárendeltségéből kilépve, saját, önálló létkörében egy-egy uralkodó szerepet tölthet be. Azonban az önállósulásnak a teljes építészeti mű szempontjából is szükségszerűnek kell lennie.

Nem elvont formulák szervezik az építészeti rendszereket, hanem a művészi élmény kifejlődésének törvényszerűségei, amelyekben végső fokon maga az ember tükröződik. Az építészeti tereknek ezt a jellegét húzzák alá, kísérik, domborítják ki a freskók, mozaikok, szobrok s ezeken kívül minden társművészeti alkotás. [1]

\section{Történeti fordulópontok}

A téma összetettsége miatt indokolt, hogy a történeti hátteret röviden bemutassam, építészettörténeti és művészettörténeti oldalról is. A kutatás időbeli origója a magyar vonatkozáshoz kapcsolódóan az európai romanika kora. Ennek lényegét két fordulópontban jelöltem meg.

Az első, hogy a legmagasabb szintű összművészeti alkotások a középkorban valósultak meg és a gótikus katedrálisban teljesedtek be utoljára ösztönösen. Ekkor még az emberek nemcsak egy alkotást építettek, de egy emberként, egy közös hit eredményeképpendolgoztak.

A második, hogy az újkorban a képek elkezdtek önállósulni, lekerültek a falról és önálló táblaképként kerültek vissza. A barokk művészetben még utoljára sikerült megvalósítani a Gesamtkunstwerk-et, 
ismét az épület mellé állt a festészet és a szobrászat is, hogy együttesen teremtsék meg a barokk térélményt, de ezután az építészet végérvényesen beolvadt a többi művészeti ág közé. Az összművészeti alkotások után már jelentős kapcsolatok, metszetek ritkán és csak kivételes esetekben valósultak meg az építészet és a képzőművészet között.

Prof. Puhl Antal Barokk tér barokk képkeretben- című esztétika MA szakdolgozatában „azt állítja, hogy a reneszánsz korszellem individualizmusa, az alkotók öntudatra ébredése és térfelfogása volt az, mely megakasztotta a középkorig tartó „őszművészetet”. Konkrétan ez az a pillanat volt, amikor a kép „lejött a falról” és a teret a képkeret segítségével „rabul ejtette”." [2]

A Vaux le Vicomte kastély a Gesamtkunstwerk csúcsa. Prof. Puhl Antal szerint a barokk kastélyokban „az építészet vezetésével a festészet és szobrászat, valamint a kertművészet ugyanazon elvekre alapozva ugyanazon cél érdekében egyesül. A nóvum az egyházi művészetnél már látott „őszművészethez” képest a kertművészet csatlakozása az építészethez és a képzőművészethez." [3]

„A Vaux Le Vicomte kastélyban létrejön ismét a „Gesamtkunstwerk”, soha nem látott kiterjedésében, s ez egy pontos dátumhoz is köthető: 1661. augusztus 17. Ekkor adják át a kastélyt XIV. Lajos, a Napkirály jelenlétében, egy barokk pompával megrendezett ünnepségen. Itt mutatják be a fényekkel földíszített parkban a kor nagy drámaírójának, Molière-nek ez alkalomra írt Kotnyelesek (Les Fâcheux) című komédiáját, ahol maga a szerző játssza a főszerepet. Jean-Baptiste de Lully, az olasz származású barokk zeneszerző a francia operastílus, az udvari balett és a zenés vígjáték megalkotója erre az alkalomra balettet komponál.

1661. augusztus 17-én egy napra hatalmas barokk pompa keretében együtt jelenik meg az összes művészeti ág, s ez soha vissza nem tér már." [4]

\section{3. Átmeneti formálódások}

A barokk beteljesülése után tulajdonképpen le is zárult a nagy önálló stíluskorszakok időszaka. Ezt követően a századfordulóig még folyamatosan próbálkoznak újat alkotni, de ezek már csak a korábbi korok puszta utánzásai, tartalmi újítást nem tudtak a formához rendelni, úgy mint ahogy az még a reneszánszban sikerült. Természetesen a létrejött alkotások művészeti értéke nem kérdőjelezhető meg, csak a mélyebb tartalmukban érheti őket kritika.

A szecesszióban fogalmazódott meg az addig nem létező nemzeti építészetünk megteremtésének igénye. Ebben Lechner Ödön volt az úttörő sajátos ornamentikájának formavilágával. Azonban igazi áttörést nem tudtak elérni, mert a stílus megragadt az ornamentika szintjén. A teljes architektúrát összefogó egységes stílus nem valósult meg azóta sem.

"A nagy tömeg divatnak tekinti, pedig az egy nagy világátalakulás első, igénytelen előcsatározása"[5] írta Ady Endre, akinek az egyéninek, az újnak, az életnek szimbólumát és az elmaradott eszmék elleni harcot jelentette a szecesszió.

A XX. század elején az avantgárd és a modernizmus hatottak. A két világháború között a Bauhaus és modern építészet funkcionalizmusának megjelenése a fő újdonság. A Bauhaus az összművészeti alkotás létrehozására törekedett, ez azonban elméleti síkon maradt, sokkal fontosabb, hogy a 
művészet és ipar, a művészet és technika közötti szakadékot kívánta áthidalni. A második világháború pusztítása után újra önmagára kellett találni a művészetnek, majd sorra születtek az új stílusok és irányzatok.

\section{Kortárs összemetsződések}

A történeti fordulópontok és az átmenti formálódások ismeretében a kortárs magyar építészet és képzőművészet összemetsződéseit három kategóriába soroltam: metamorfózis, illeszkedés és metszet.

Metamorfózisnál a művészeti műfajok átlépik egymás határait, átváltoznak. A képzőművészeti alkotások épületekké, legalábbis építészeti elemmé formálódnak, az épületek pedig képzőművészeti alkotássá. Ez azonban szinte csak elméleti síkon játszódhat le. Az épület embereknek épül, emberi teret határol, amit emberek használnak. Egy szobornak nincs használati rendeltetése, kizárólag esztétikai funkció miatt alkotják meg. Tehát az épület nem válhat szoborrá. Egy szobrot, festményt, vagy művészeti installációt bizonyos szinten lehet építészetnek nevezni, de épületnek sosem. Ezért ez a kategória inkább elméleti és kísérleti szinten jelentős. Konkrét példa metamorfózisra Megyik János táblaképeinél lesz elemezve. A táblaképekre, mint háttérre szüksége volt Megyiknek, hogy megalkothassa a Kapuzatát.

A felhasznált anyagok szintjén szintén létrejöhet szintézis, az anyag is lehet a képzőművészeti alkotás és az épület közös nevezője. Ilyenkor valós metamorfózis nem történik, az anyag ugyanaz az anyag marad, de tartalmilag átalakul, ami által az építőanyag művészi rangra emelkedhet.

Jovánovics György gipsz alkotásainak felületén megdöbbentő erejü hatások rajzolódnak ki. Gipsz öntvényeit a kiöntött anyag textúrája és szerkezete határozza meg. A gipsz átformálódik, felveszi egy másik anyag tulajdonságait, ugyanakkor a saját elementáris hatása is érvényesül ami által elgondolkodtató szintézis jön létre. A felületeknek ezt a játékát térbeli szobrokon fokozza tovább. A létrejövő konstrukciók elvontépítészeti tartalommal telítődnek.

Illeszkedésnél a magában is önálló képzőművészeti alkotás kapcsolódik az architektúrához. Különkülön is megállnák a helyüket, azonban csak a kettő együtt alkot teljes egységet. Itt már egyértelmű és a hétköznapokban is konkrétabb példákat láthatunk, ezért ez a kategória áll legközelebb az emberekhez.

A középkorig az épület, és elsősorban a fal volt a képzőművészeti alkotások felülete, a falra festettek. Aztán a reneszánszban a kép önállósult, keretet kapott és fokozatosan elszakadt a faltól. Ma már egyáltalán nem jellemző a közvetlen falra festés. A városokban viszont a 1980-as években kialakult és napjainkban művészeti ággá nőtte ki magát a street art (utcai művészet) - köztéri művészet. A street art egyik ága a graffiti, de nem tévesztendő össze vele, valóban van művészi létjogosultsága. Hivatásos művészek és az utca embere is egyaránt véleményt formálhatnak közvetlenül az utca díszleteire, a falakra festve. A street art-ot is az építészet és a képzőművészet kapcsolatának érzem, illeszkedésnek, ugyanis nagyon sokszor a fal hibáit, különlegességeit használják fel, domborítják ki a művészek, elsősorban az emberi szerepe miatt. A street art alkotások az emberek közvetlen szócsövei, múvészetbe ágyazott kíméletlen társadalomkritikát, iróniát, véleményt mondhatnak általa, de a társadalmi tartalmon kívül a művészeti tartalom önmagában a lényeg. Meglepő ereje a 
váratlanságában és a közvetlenségében van, ha csak pár másodpercre is, de egy ilyen alkotás kiszakít a hétköznapokból, gondolkodásra késztet.

A magyar kortárs művészet kapcsolatait az illeszkedés szempontjából napjaink egyik legjelentősebb alkotása, a budapesti 4-es metró 2014-ben átadott megállói. Alapvetően a 4-es metró a főváros egy műszaki létesítménye a föld alatt, amit magas szintű építészeti tartalommal megalkotott megállók kötnek össze a felszínnel, ráadásul a megállók architektúrájába illeszkedő képzőművészeti alkotásokkal igazán sokszínű szintézis valósul meg. A 4-es metró azért az egyik legjobb példa az illeszkedésre, a kortárs építészet és képzőművészet kapcsolatára, mert itt tényleg a kor igényeinek megfelelően, a technikai csúcsteljesítmény és mérnöki prioritások mellett is nyitottak a művészet felé. Ez érezhető is az emberi terekben.

Az előzőleg bemutatott két alternatíva után úgy gondolom, hogy a metszet az kategória, ahol ma a legmagasabb szintre emelkedhet és emelkedik is építészet és képzőművészet összemetsződése, és valódi metszetek jönnek létre. Ezt az összemetsződést teljes egészében Megyik János életművének és művészetének rövid ismertetésével mutatom be. Megyik János debreceni Kapuzatának megértéséhez elengedhetetlen ismerni a közvetlen hátteret, Megyik János művészetét. A művészete viszont annyira összetett, hogy szinte az egész kortárs elemzésemet lefedi, így újra érintenem kell a metamorfózis témakörét is.

Megyik János képzőművész festőnek készült, és mindmáig festő is maradt, csak éppen nem hagyományos festményeket készít, hanem háromdimenziós táblaképeket. Megyiket az érdekli, hogy a kép hogyan tud térbe lépni, a Kapuzat szobra pedig ez alapján maga a kép tere.

A képeken is látható fapálca konstrukciói és acéllemez alkotásai térbeli létük ellenére a táblaképek megújításának lenyomatai. Alkotásainak alapja, hogy projektív geometriával szerkeszti a perspektívát, melynek lényege, hogy figyelmen kívül maradnak mind a méretek, az irányok, a szögek és a párhuzamosok is. A végtelent jelentő enyészpont a képen kívülre, maga a horizont a képsík legfelső vízszintes egyenesére kerül. Ráadásul több szem-pontból indulhat a perspektíva. „Megyik bármely alkotása prizma, a világ sürítése." [6]

Megyik János Kapuzata és Golda Jánosék épülete olyan alkotások, amelyek egymás nélkül nem lennének teljesek. A szobor szobor marad, de mégis elválaszthatatlanul kapcsolódik az épülethez. Ezen a szinten nem is a kapcsolat a lényeges, hanem sokkal inkább az a tér, ami a két alkotás összemetsződése. Ez a tér, pontosabban űr determinálja az egész alkotást, mint egységet. Egyfajta ablakként is funkcionál, a környezetét hangsúlyozza. A kaput körülvevő ősfás liget a méltóságteljes évszázados kocsányos tölgyeivel meghatározó elemi erővel hat. Ahogyan a fák árnyékai nekifeszülnek a vasbeton és réz felületnek, érezni a természet erejét. De a lombkoronákon átszűrődő napfény által mégis finom érzékenységgel mosódnak össze a homlokzatok textúrájával az árnyékok. Nem csak építészet és képzőművészet korunk legmagasabb szintű szintézise teljesedik ki a Kapuzat által, de napjaink egyik legfontosabb kérdését is nagyszerűen megválaszolja, mivel a technika és természet tökéletes összhangban kapcsolódnak egymáshoz. Nemcsak a metszet, de a másik két szempontom, a metamorfózis és az illeszkedés is érvényesül. A szobor megmarad szobornak, de olyan magas szinten alkot egységet az épülettel, hogy emberi teret hoz létre. Ez a tér mély gondolatvilággal bír, a szobor 
lábánál végigfutó szökőkút csobogása által kiegészülve minden érzékszervünkre hat és ha ehhez még a napfény által a környező természet is beszivárog, szinte transzcendens élményt teremt.

\section{Technika és építészet - körkorkép}

Az ipari forradalomtól kezdve számtalan új építőanyag és szerkezetek variációi jelentek meg. Csak egy konkrét példát emelnék ki: Losonczi Áron 2002-ben feltalálja a fényáteresztő betont, melynek elemi kontrasztja teljesen új anyagi- vizuális- és gondolati megközelítéseket generál. [7]

Egy másik sokatmondó példa, az ornamentika mai szerepének megváltozása, eltűnése. „A mai értelemben vett dekorativitás elsősorban a funkció és szerkezet logikája szerint elrendeződő anyag természetes tulajdonságai folytán közvetlenül a tartalomból születik." [8] Azonban az anyagi és szerkezeti megoldások nem képzőművészeti alkotások, hanem a hiányuk okozta űr kitöltésére szolgálnak.

„Az építészet felemelkedése szinte szó szerint érthető, amióta a high-tech robbanásszerű fejlődésének és a kompjuteres tervezésnek köszönhetően minden megcsinálható. A szürke házsorok hátteréből plasztikus építmények emelkednek ki, háromdimenziós képek, amelyek hideg bravúrral kubistafuturista festők álmait ültetik át a XXI. századba." [9]

Az elképesztő formákat öltő épületek egyre organikusabbak. Paradox módon, amikor már teljesen elszakította a technika az embereket a természettől, egy saját maga által létrehozott, úgymond mesterséges természet elérése a cél.

\section{Összefoglalás}

A különböző történeti, technikai, szellemi fejlődés és fordulópontok hatására a kortárs építészetet és képzőművészetet annyira sokrétű és szövevényes kapcsolatok hálózzák be, hogy a metszetek csak hasonló alternatívaként jöhetnek létre. A mai folyamatosan változó világban az önállósult és független embert képezi le a minden téren zajló rétegződés, szeparálódás. A rendelkezésünkre álló felfoghatatlan mennyiségű információ kezelésére természetes válasz az, hogy mindent külön kategóriákba sorolunk. Ez az építészetben és a képzőművészetben is azt eredményezte, hogy az egyes ágak teljesen elmerülnek önmagukban, specializálódnak, ezáltal redukálódik a párbeszéd. A középkorban még teljes összhangban, egy emberként dolgozott minden ember, hogy az adott épület teljes mértékben reprezentálja a világról alkotott képüket. Ezt a közös munkát kellene korunkban erősíteni úgy, hogy a szétszakadt ágak együttesen alkossanak. Az én központú és a virtuális világba révedő társadalmunkban egyre nagyobb igény van a közösségépítésre.

Egy tökéletes magyar példa a közös építésre és a közösségépítésre, amikor Pozsár Péter többedmagával létrehozza a Hello Wood nemzetközi alkotócsoportot. 2010 óta, nyaranta szerveznek alkotótáborokat abból a célból, hogy a különböző művészeti területekről érkező hallgatók kétkezi munkával, a saját tapasztalataikon keresztül tanulhassanak. A tervezés és alkotás folyamatában is a közösség ereje érvényesül. A Hello Wood mára igazi nemzetközi programmá nőtte ki magát, egy mozgalom indult el. Alapanyaguk a fa meghatározza a természet közeli szemléletet. 
Az építészet és technika kapcsolatának tárgyalásánál felvázolt körkorkép elsősorban a világ vezető nagyvárosaira jellemző. Magyar viszonylatban még nem tapasztalható ez a szélsőséges elszakadás, de nálunk is ugyanazok a folyamatok zajlanak. Úgy gondolom, azon kevés nemzetek közé tartozunk, akiknek még sikerült megőrizni kapcsolatukat a múltjukkal és a természettel, ezáltal keresik helyüket a mai világban. Megyik János Kapuzata és a 4-es metró megállói, valamint a Hello Wood projekt bizonyítja, hogy még ma, a technika világában is létrejöhetnek magas szintű és minőségi metszetek az építészet és a képzőművészet között.

Korunk kihívásai ellenére, a művészet sosem fog eltűnni, de ha elveszíti kapcsolatát a társadalommal, akkor csak nagyon kevesek kiváltságává válik.

Az építészet és képzőművészet lényege, sőt alapja az ember. Sosem szabad elfelejteni, hogy embereknek tervezünk, emberek fognak az épületünkben élni. Ha az emberek nem értik a múvészetet, akkor nincs is rá igényük. És ez a legfőbb oka a kortárs metszetek távolodásának. A művészet, mivel nincs értő közönsége, bezárkózott a saját világába és nem is törekszik kapcsolatot teremteni az emberekkel. Az ellentét feloldása minkét oldalról cselekvést igényel, de a legfontosabb, hogy az embereknek kellene igényelni a művészeteket, ezt pedig csak megfelelő művészeti nevelés által alakítható ki.

\section{Köszönetnyilvánítás}

Köszönetemet szeretném kifejezni Török Dávid konzulensemnek, Puhl Antal Professzor Úrnak, Csüllög Mihálynak és Kovácsné Szabó Ágnesnek. Iránymutatásuk és támogatásuk nélkül nem készülhetett volna el a dolgozatom.

\section{Hivatkozások}

[1.] Pogány Frigyes: Szobrászat és festészet az építőművészetben. Műszaki Könyvkiadó, 1959. p. 491-516.

[2.] Puhl Antal: Barokk tér barokk képkeretben, Esztétika MA szakdolgozat, DE Filozófiai Intézet, Debrecen 2015. p. 5.

[3.] Puhl Antal: Barokk tér barokk képkeretben, Esztétika MA szakdolgozat, DE Filozófiai Intézet, Debrecen 2015. p. 47.

[4.] Puhl Antal: Barokk tér barokk képkeretben, Esztétika MA szakdolgozat, DE Filozófiai Intézet, Debrecen 2015. p. 50-51.

[5.] Gellér Katalin: A magyar szecesszió. (Stílusok - korszakok sorozat) Corvina Kiadó, 2004. p. 19.

[6.] András Sándor: A táblakép színeváltozásai - Megyik János műveiről. In: Imre Györgyi (szerk.): MegyikJános: A kép tere. Budapest: Ludwig Múzeum - Kortárs Múvészeti Múzeum, Budapest, 2012. p. 213. 
International Journal of Engineering and Management Sciences (IJEMS) Vol. 1. (2016). No.2.

DOI: 10.21791/IJEMS.2016.2.15.

[7.] A fényáteresztő beton in: http://epiteszforum.hu/a-fenyatereszto-beton (Letöltés időpontja: 2016.06.10.)

[8.] Pogány Frigyes: A szép emberi környezet. Budapest: Gondolat Kiadó, 1976. p. 390-392.

[9.] Glózer László: A változások kertjében. In: Janesch Péter (szerk.): széptól szépig [és vissza] (9. Nemzetközi Építészeti Kiállítás, Velencei Biennále Magyar Pavilon, 2004.09.09. 2004.11.07.) Budapest: Mű́csarnok, 2004. p. 21. 